\title{
ASSESSING THE EXTENT AND CONTRIBUTION OF OECMS IN SOUTH AFRICA
}

\author{
Daniel Marnewick ${ }^{1,2} *$, Candice M.D. Stevens ${ }^{3}$, Harry Jonas ${ }^{4}$, Romy \\ Antrobus-Wuth $^{5}$, Natasha Wilson ${ }^{6}$ and Nicholas Theron ${ }^{5}$ \\ * Corresponding author: daniel.marnewick@iucn.org.za \\ ${ }^{1}$ BirdLife South Africa, South Africa \\ ${ }^{2}$ IUCN Eastern and Southern Africa Office, South Africa \\ ${ }^{3}$ Wilderness Foundation Africa, South Africa \\ ${ }^{4}$ Future Law, IUCN-WCPA OECM Specialist Group, Malaysia \\ ${ }^{5}$ Kruger to Canyons Biosphere Region NPC, South Africa \\ ${ }^{6}$ South African National Biodiversity Institute, South Africa
}

\section{ABSTRACT}

In 2018, Parties to the Convention on Biological Diversity (CBD) adopted a definition and criteria for identifying other effective area-based conservation measures (OECMs). South Africa is one of the first countries to undertake a comprehensive national review of its potential OECMs. Previous research results already estimated that 48.5 per cent of sites within South Africa's unprotected Key Biodiversity Areas could potentially meet the OECM definition. A subsequent multi-stakeholder study provided an opportunity to assess the alignment between OECMs and national conservation policy and practice, to further determine the potential extent of OECMs, and whether OECMs may strengthen the country's collective conservation estate. This study led to several findings. First, the OECM framework facilitates the formalisation, expansion and reporting of South Africa's conservation areas estate. Second, OECMs strengthen interconnected landscapes and seascapes alongside protected areas. Third, OECMs can include a diverse range of rights-holders contributing to area-based conservation, including previously marginalised groups, land use types and sectors. Fourth, OECMs play a role in supporting local economies that are simultaneously safeguarding environmental assets. A significant challenge remains to leverage financial and human resources to assess, report, monitor and support OECMs, without diverting resources from other conservation priorities, especially protected areas.

Key words: Convention on Biological Diversity, area-based conservation, conservation estate, sustainable landscape

\section{INTRODUCTION}

In 2010, Parties to the Convention on Biological Diversity (CBD) agreed on the Strategic Plan for Biodiversity (2011-2020). In this Plan, Aichi Target 11 calls on Parties to conserve 17 per cent of terrestrial and freshwater areas and 10 per cent of marine and coastal areas through well-connected systems of protected areas and other effective area-based conservation measures (OECMs). Parties to the CBD subsequently defined 'other effective area-based conservation measure' as:

A geographically defined area other than a Protected Area, which is governed and managed in ways that achieve positive and sustained long-term outcomes for the in-situ conservation of biodiversity, with associated ecosystem functions and services and where applicable, cultural, spiritual, socio-economic, and other locally relevant values. (CBD, 2018)
In light of the advent of the definition and criteria for identifying OECMs (CBD, 2018) and IUCN guidelines for Recognising and Reporting OECMs (IUCN-WCPA, 2019), there is a need to assess the potential extent of OECMs and whether the OECM designation strengthens the national conservation estate in South Africa.

In a previous study that assessed the prevalence of potential OECMs in 740 terrestrial Key Biodiversity Areas (KBAs) ${ }^{1}$ outside known or mapped protected areas across ten countries, indications were that the majority of unprotected KBAs (76.5 per cent) were at least partly covered by one or more potential OECMs (Donald et al., 2019). These and other (Dudley et al., 2018) results provide strong evidence that OECMs could complement protected areas to fulfil their original intent in Aichi 
Target 11. An estimated 48.5 per cent of sites in South Africa's unprotected KBAs had underlying governance and management characteristics that potentially met the OECM definition (Donald et al., 2019). Based on these findings, South Africa undertook a comprehensive national review of potential OECMs (Marnewick et al., 2020). This paper provides an overview of the extent, opportunities and challenges in the South African context.

\section{SOUTH AFRICAN CONTEXT: BIODIVERSITY STEWARDSHIP}

South Africa is a world leader in systematic biodiversity planning, biodiversity reporting, protected area legislation and protected area expansion, particularly on non-state land (SANBI, 2018; Stevens, 2019; Wright et al., 2018). South Africa defines a protected area as a geographically defined area of land or sea that is formally protected in terms of the National Environmental Management: Protected Areas Act No. 57 of 2003 (The Protected Areas Act) (DEA, 2003) and managed mainly for biodiversity conservation. In addition to protected areas, South Africa also recognises 'conservation areas'. South Africa defines its conservation areas as areas of land or sea that are not formally protected in terms of The Protected Areas Act but are nevertheless managed at least partly for biodiversity conservation (SANBI, 2016). Conservation areas contribute towards the country's broader conservation estate but not the protected area estate (SANBI, 2016). South Africa's conservation estate is an inclusive term referring to all protected areas and conservation areas (SANBI, 2016). South Africa's policy and legislative framework illustrates the distinction between protected areas and conservation areas. Protected areas and conservation areas in South Africa are recognised and reported on separately. Biodiversity stewardship is South Africa's primary tool for expanding the country's conservation estate. Biodiversity stewardship is a state-led initiative that involves securing land in biodiversity priority areas through voluntary agreements with private landowners, Communal Property Associations and the occupiers of communal land. Biodiversity stewardship is led by conservation authorities and supported by conservation NGOs (SANBI, 2018).

The biodiversity stewardship framework consists of a hierarchy of agreements under three categories: 1. Protected Areas (as defined above), 2. Conservation Areas (as defined above), and 3. Biodiversity Partnership Areas (SANBI, 2018, see Table 1). Category 1 includes state-owned protected areas and 'contract'2 protected areas (SANBI, 2016). Between 2008 and

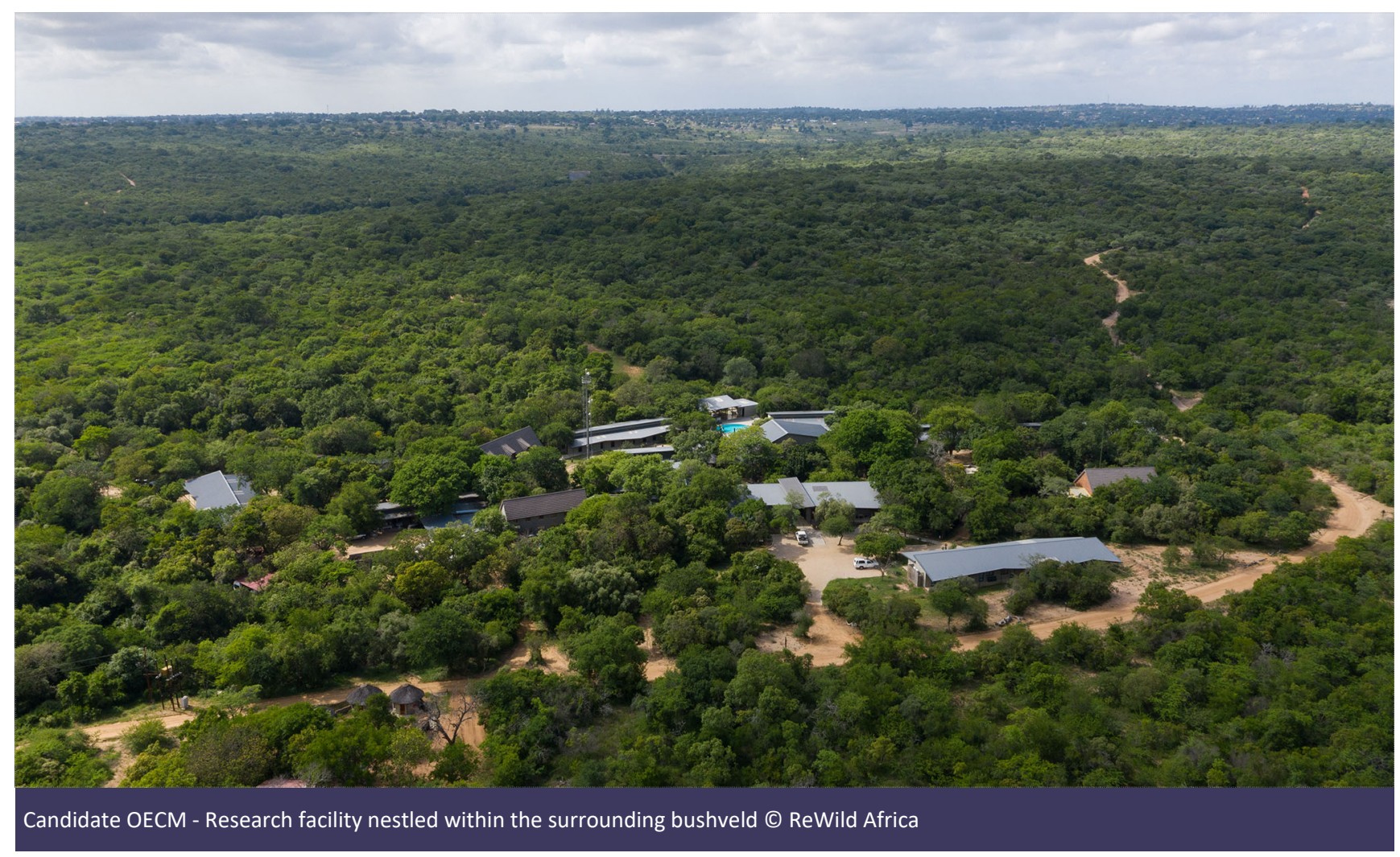


Table 1. Biodiversity stewardship categories (SANBI, 2018)

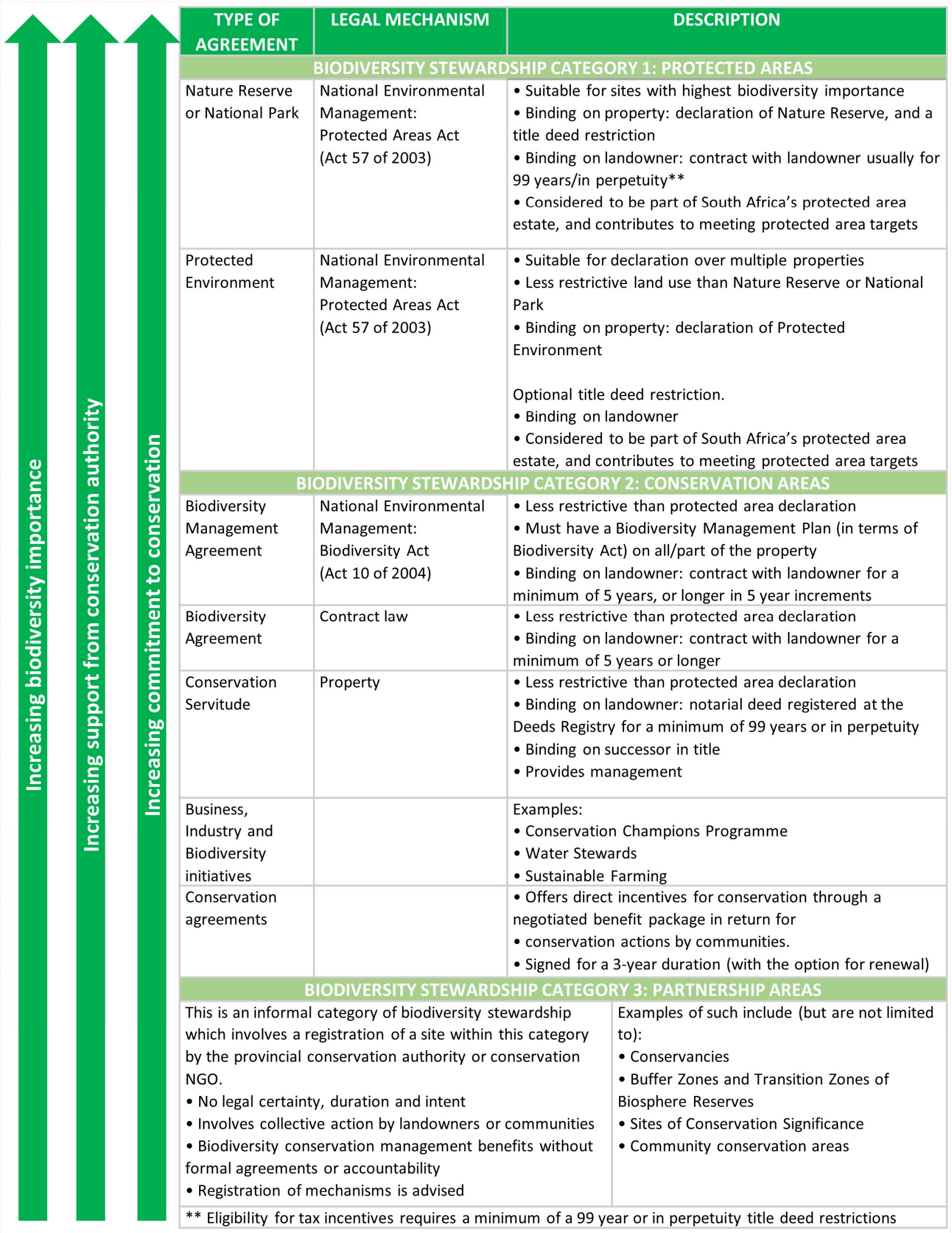


2016, 68 per cent (564,00o hectares) of all 'contracted' protected area expansion was achieved through biodiversity stewardship agreements (SANBI, 2018).

Category 2 provides for conservation areas described in the National Biodiversity Strategy and Action Plan as contributing to the broader conservation estate (DEA, 2015). South Africa has a government held database, the Protected Areas Conservation Areas (PACA) database, which records all protected and conserved areas in the country. As a result of this country specific context, South Africa historically reported both its protected areas as well as its conservation areas separately to the World Database on Protected Areas (UNEP-WDPA) and did so even before Parties to the CBD agreed on the definition of an OECM (CBD, 2018) and before the new UNEP database on OECMs was created. As a result of the acceptance of the OECM definition, South Africa can now formally assess its category 2 conservation area sites as OECMs. The assessments will allow for South Africa to report those conservation areas that meet the criteria to the new World Database on OECMs.

The biodiversity stewardship approach to land conservation is an efficient area-based conservation tool which is also cost-effective (SANBI, 2017), resulting in both protected and conserved areas. It offers a clear example of the interplay between privately protected areas and OECMs (Mitchell et al., 2018) and a clear framework within which South Africa's OECM national review took place.

\section{METHODS}

A country level assessment for South Africa was undertaken through a government and private partnership to determine the types and potential extent of OECMs in South Africa (Marnewick et al., 2020). The study broadly aimed to, 1) assist South Africa to institutionalise OECMs into its existing policy frameworks, and 2) align OECMs with the biodiversity stewardship community of practice, facilitating the full integration of all possible initiatives across South Africa that meet the OECM definition into biodiversity stewardship (Figure 1). The results provide empirical evidence and a detailed technical analysis of the prevalence and characteristics of effective conservation occurring outside of the South African protected area network. The country study results also informed the ongoing development of the IUCN's Site-level methodology for identifying other effective area-based conservation measures (IUCN-WCPA, Forthcoming).

To test the CBD definition and IUCN guidelines within a national context, the study aimed to achieve seven key objectives (Marnewick et al., 2020) which were implemented in three phases, of which key elements are presented below.

Phase 1 of the study included undertaking a national technical review pertaining to South Africa's legislative and policy frameworks and their interplay with the OECM definition. This review included identifying all potential OECMs and developing the first draft list of potential OECMs. This initial list included all known conservation areas under biodiversity stewardship categories 2 and 3, sites assessed in the study of Donald et al. (2019), and additional types of conservation areas considered to have OECM type characteristics.

Phase 2 included stakeholder engagement in workshops, focus groups and one-on-one interviews with area-based conservation experts and practitioners. The study invited all relevant national stakeholders to three workshops. Forty-three (43) participants from the government, the private sector and civil society attended the first two stakeholder workshops. Nineteen (19) participants from the government, the private sector and civil society attended the third workshop which specifically engaged with stakeholders for the case study
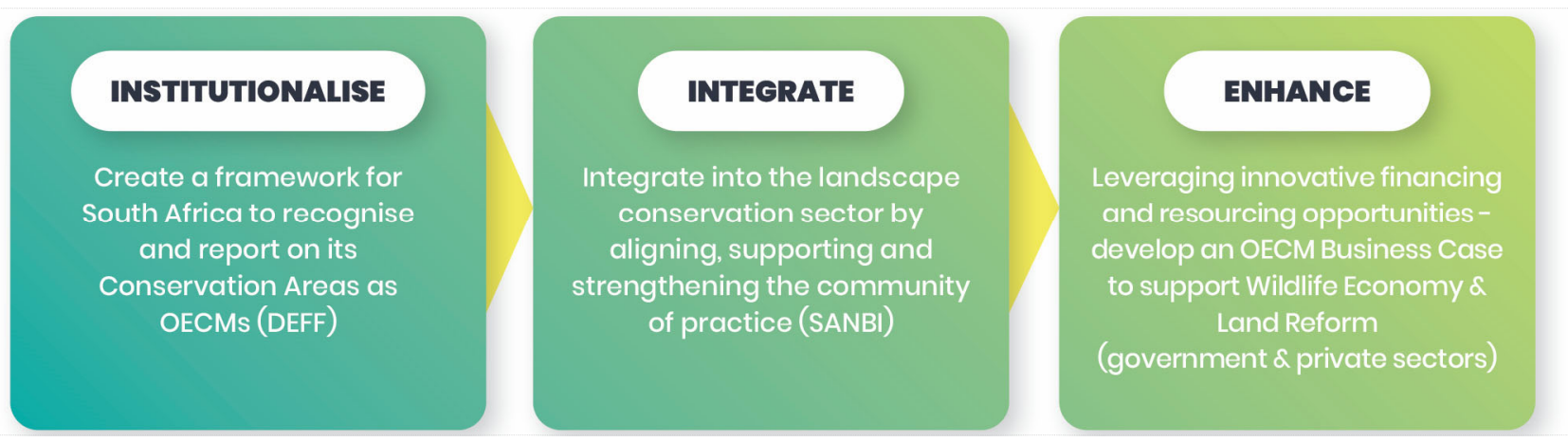

Figure 1. Key objectives and outcomes for the furthering of OECM work in South Africa 
sites. The study also presented OECMs at several strategic meetings, workshops and conferences, including to the Biodiversity Stewardship Technical Working Group. In the first two extensive stakeholder workshops, the technical review and list of potential OECMs was presented and refined (Supplementary Online Material Table S1).

The list of potential OECMs was critical because it facilitated the selection of case study sites and broadly allowed the community of practice to refine sites for future assessment. A potential OECM is a geographically defined space that has been identified as having OECM-like characteristics by applying the screening tool but where the governance authority has yet to consent to it becoming a 'candidate OECM' (IUCN-WCPA, 2019). A candidate OECM is a geographically defined space that has been identified as a 'potential OECM' and the governance authority has consented to it being assessed against the CBD criteria (IUCN-WCPA, 2019).

Phase 2 also yielded the selection of a case study area. Due to its status and diverse ownership, governance and land use types, the Kruger to Canyons Biosphere Region (K2CBR) was identified as a suitable region to conduct the case study site assessments on potential OECMs. Assessing potential OECMs in the mosaicked configuration of protected areas and conservation areas found in the $\mathrm{K} 2 \mathrm{CBR}$ also tested the complementary value of OECMs in such a conservation landscape (Figures 2 and 3).

Phase 3 focused on assessing the nine case study sites in the K2CBR, representing six types of potential OECMs (Table 2). Upon consent from the respective governance authorities, each site was assessed on its own merits as a candidate OECM, using the site assessment tool designed for this purpose (see below). Sites were assessed by representative(s) from the project partners and representative(s) of the sites' governance and/or management authority. The results from the site assessments were presented and discussed at the third stakeholder workshop, which also included site representatives.

Throughout the above phases, the study aimed to integrate OECMs into the national context. A project

Table 2. Potential OECM site performance against the OECM characteristics, using the 3-grade rating scale

\begin{tabular}{|c|c|c|c|c|c|c|c|c|c|}
\hline \multicolumn{5}{|c|}{ Site Type } & \multicolumn{5}{|c|}{ OEGM Characteristies } \\
\hline \# & $\begin{array}{l}\text { Candidate } \\
\text { OECM Type }\end{array}$ & $\begin{array}{l}\text { Governance } \\
\text { Type }\end{array}$ & $\begin{array}{l}\text { Governance } \\
\text { Authority }\end{array}$ & $\begin{array}{l}\text { Management } \\
\text { Authority }\end{array}$ & $\begin{array}{l}\text { Biodiversity } \\
\text { Value }\end{array}$ & $\begin{array}{c}\text { Geographically } \\
\text { Define }\end{array}$ & Governance & Management & Effectiveness \\
\hline 1 & $\begin{array}{l}\text { Private Game } \\
\text { Reserve }\end{array}$ & $\begin{array}{l}\text { Privately } \\
\text { Owned }\end{array}$ & $\begin{array}{l}\text { Board of } \\
\text { Trustees; } \\
\text { Constitution }\end{array}$ & $\begin{array}{l}\text { Pvt. Management } \\
\text { Company. } \\
\text { Home-owners } \\
\text { association }\end{array}$ & $\approx$ & $\approx$ & $\approx$ & $\Rightarrow$ & $\approx$ \\
\hline 2 & $\begin{array}{l}\text { Private Game } \\
\text { Reserve }\end{array}$ & $\begin{array}{l}\text { Privately } \\
\text { Owned }\end{array}$ & $\begin{array}{l}\text { Family trust; } \\
\text { Constitution }\end{array}$ & None & $\approx$ & 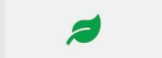 & $\approx$ & $\varnothing$ & 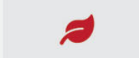 \\
\hline 3 & $\begin{array}{l}\text { Ecotourism } \\
\text { Establishment }\end{array}$ & $\begin{array}{l}\text { Private } \\
\text { Company }\end{array}$ & $\begin{array}{l}\text { Private company } \\
\text { (Companies Act) }\end{array}$ & $\begin{array}{l}\text { Company } \\
\text { Directors }\end{array}$ & 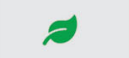 & 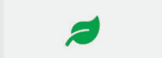 & $\rightleftharpoons$ & 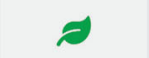 & Æ \\
\hline 4 & Military land & State Owned & $\begin{array}{l}\text { South African } \\
\text { Defence Force }\end{array}$ & Air Force Base & $\approx$ & 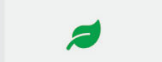 & $\approx$ & $\approx$ & 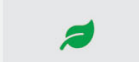 \\
\hline 5 & $\begin{array}{l}\text { Sustainable } \\
\text { Agriculture/ Forestry }\end{array}$ & State Owned & $\begin{array}{l}\text { State Department } \\
\text { (across three } \\
\text { departments) }\end{array}$ & $\begin{array}{l}\text { State owned } \\
\text { company }\end{array}$ & $\approx$ & 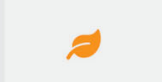 & $\rightleftharpoons$ & $\approx$ & 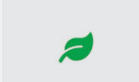 \\
\hline 6 & $\begin{array}{l}\text { Academic Institution } \\
\text { Land }\end{array}$ & University & $\begin{array}{l}\text { University } \\
\text { governance } \\
\text { structures }\end{array}$ & $\begin{array}{l}\text { University's natural } \\
\text { sciences academic } \\
\text { department; infrastructure } \\
\text { by Services Department }\end{array}$ & 2 & $=$ & $\Rightarrow$ & $=$ & 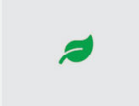 \\
\hline 7 & $\begin{array}{c}\text { Conservation } \\
\text { Agreement } \\
\text { (with 3rd party) }\end{array}$ & $\begin{array}{l}\text { Communally } \\
\text { owned land }\end{array}$ & $\begin{array}{l}\text { Community } \\
\text { Development Forum; } \\
\text { Traditional Authority }\end{array}$ & $\begin{array}{l}\text { Traditional Authority; } \\
\text { Farmer's Cooperative. }\end{array}$ & $\approx$ & $\approx$ & $\approx$ & 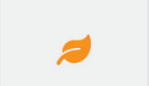 & - \\
\hline 8 & $\begin{array}{c}\text { Community } \\
\text { Conservation Area }\end{array}$ & $\begin{array}{l}\text { Communally } \\
\text { owned land }\end{array}$ & Traditional Authority & Traditional Authority & $\approx$ & 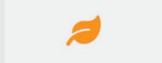 & $\approx$ & $\approx$ & $\approx$ \\
\hline 9 & $\begin{array}{l}\text { Community } \\
\text { Conservation Area }\end{array}$ & $\begin{array}{l}\text { Communally } \\
\text { owned land }\end{array}$ & Traditional Authority & Traditional Authority & $\approx$ & 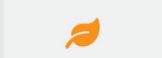 & $\approx$ & $\varnothing$ & $\approx$ \\
\hline
\end{tabular}


steering committee was established for this purpose. The committee included representatives from the study leads, case study site assessment leads and key government institutions who would be responsible for integrating OECMs into national policy and practice, and reporting OECMs.

\section{ASSESSMENT TOOL}

The OECM assessment tool was developed to test the OECM characteristics at a site level. The assessment tool was informed by the IUCN's guidelines for Recognising and reporting other effective area-based conservation measures (IUCN-WCPA, 2019) and the CBD Decision 14/8 (CBD, 2018). The tool assessed sites against the OECM characteristics using 20 criteria questions. A three-grade rating scale (yes/meeting green, partially meeting - orange, and no/not meeting - red) was used to assess each of the criteria questions. This type of analysis followed a similar analysis developed by the Canadian Council on Ecological Areas (CCEA, 2018)3. The rating scale allowed the tool to provide flexible indicators to accommodate the variability expected across various sites. The colourgrading scale also provided a visual overview of how closely a site met the OECM characteristic and where shortcomings existed.

The overall result for each site was determined by whether the site met all the characteristics, in which case it would qualify as an OECM. Sites that did not meet one or more criteria would not qualify as an OECM. A site that answered 'partially' to one or more criteria questions essentially would qualify as an OECM, albeit with certain caveats, and identifying areas needing further strengthening (Table 2). It must be noted that the global OECM methodology proposes to use a more rigorous approach to determining the final result (IUCN-WCPA, Forthcoming).

Of the nine sites assessed, the six qualifying sites constituted 59 per cent of the total 27,864 hectares assessed. The three sites that did not meet the OECM definition struggled to achieve the governance and/or management requirements. One of the privately-owned

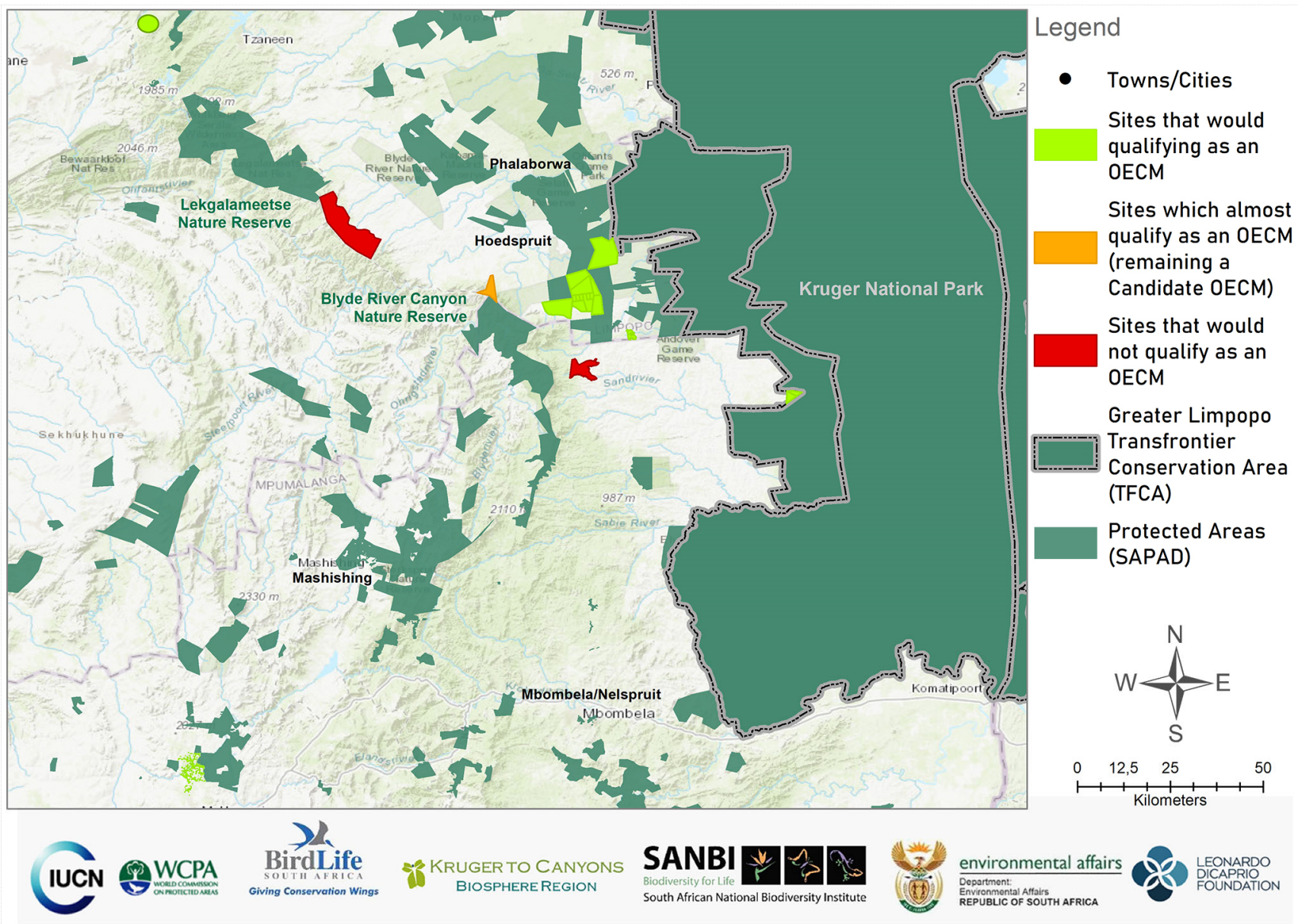

Figure 2. OECM case study assessment sites in relation to the protected area network and KBAs in the K2C Biosphere Region 
sites indicated a willingness to develop the necessary management plan to remedy the shortcoming, while the two community-owned sites required fundamental improvements in governance and management.

The results from assessing the case study sites against the five key characteristics of an OECM, namely biodiversity value, geographically defined, governance, management and effectiveness, are summarised in the full country study report (Marnewick et al., 2020).

Several key lessons were learnt from trialling this assessment tool. First, the participants found the tool simple to use. Second, the site assessment took two hours on average to complete, not including any desktop data gathering pre-assessment. Third, the governance and/or management authorities responded very positively to the assessment process. Certain sites did enquire about the benefits of being recognised as an OECM, but none expressed any concerns about being recognised as an OECM. Fourth, the representatives of the sites being assessed understood the context of the criteria questions and were able to grade themselves confidently. The only exceptions were two of the community sites. In these cases, the traditional authorities (governance authorities) did not easily understand the context or requirements of the criteria questions. Consequently, questions needed to be rephrased several times. Therefore, it is recommended that when an assessment is proposed in a rural setting with community groups or Indigenous Peoples, a series of deeper issues are considered (Jonas et al., 2017), and revising or co-developing the assessment to ensure that it is locally appropriate, including in the respective dialect, may be required (Hill et al., 2020).

The assessment tool informed the development of the global assessment methodology, and the IUCN encourages countries to use and adapt the global assessment methodology for national contexts.

\section{KEY EXAMPLES OF POTENTIAL OECMS}

Given the intent of the CBD Aichi Target 11 to conserve areas of particular importance for biodiversity and ecosystem services, it is important to note that all nine case study sites held high biodiversity value as described through national or provincial systematic conservation planning (Critical Biodiversity Areas and Ecological Support Areas), and/or are recognised by global standards (KBAs).

The below candidate OECMs met the OECM characteristics based on the assessments conducted using the assessment tool and are examples of the different governance types identified in the list of potential OECMs. The names of sites and governance bodies have purposefully been omitted, unless explicit permission was given by that institution.

\section{Candidate OECM 1: Community-owned land}

Community site 1 was the only site of the three community-owned sites assessed that met all the OECM characteristics. This site is situated between two existing protected areas, which form part of the Greater Kruger open system (Figure 3). The site is governed by a Traditional Authority, strengthened by two parallel committees, namely a Community Development Forum (CDF) and the Farmers' Cooperative. The CDF and Farmers' Cooperative provide platforms for community members to have representation in how the livestock rangelands are managed. The CDF-elected members sign the CDF constitution and are registered with the Traditional Authority Office. The Farmers' Cooperative comprises community members who have signed a Conservation Agreement with a partnering NGO, Conservation South Africa (CSA), and use the rangelands for grazing their cattle.

CSA is assisting the community in developing and implementing a management plan aimed at improving grassland grazing and burning regimes for livestock farming, which is compatible with the conservation of the natural grasslands and savannah habitat and associated species. Conservation is a secondary management objective. While the community and CSA's conservation agreement is typically renegotiated annually, this is implemented under a three to five-year partnership project, which is often also renewed. The long-term objective is to partner the community's livestock production with a corporate-based, marketdriven economic incentive scheme called 'Meat Naturally'.

This site has demonstrated the opportunity to use community-private sector partnerships, under the sustainable agriculture and wildlife economies, to drive

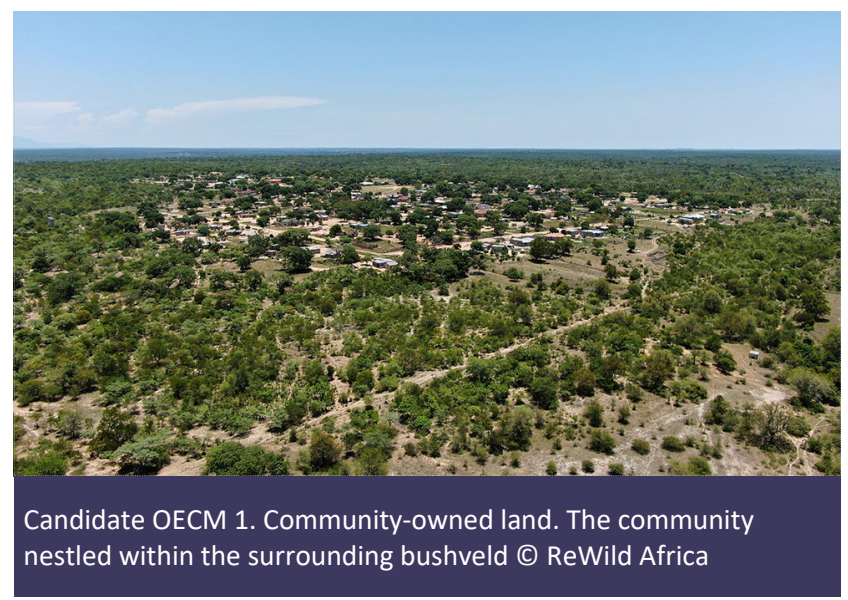




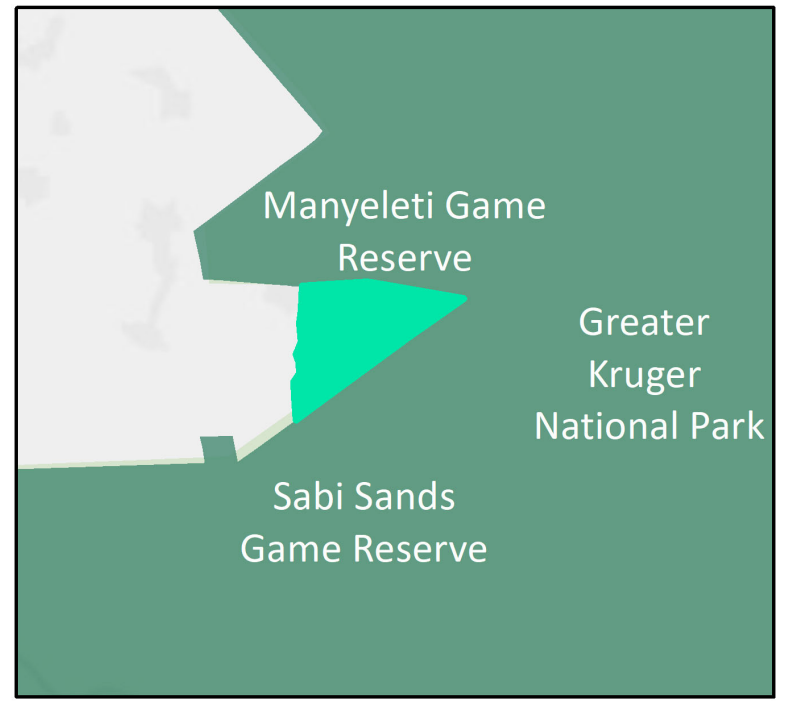

Candidate OECM 1: Community-owned Land

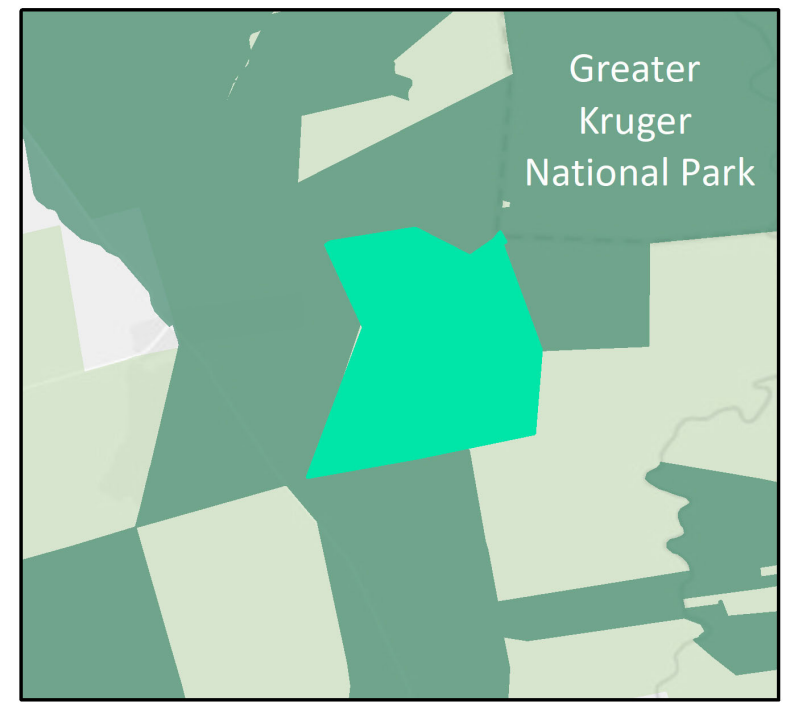

Candidate OECM 3: Government -

Airforce Base

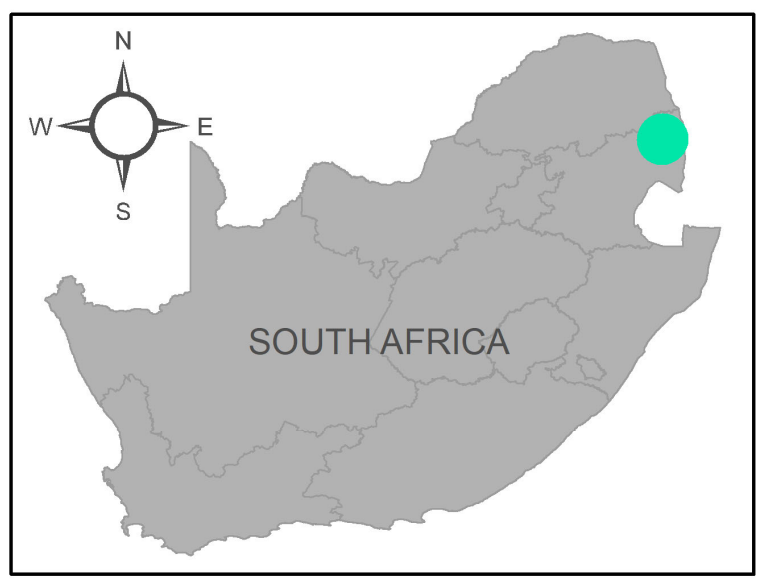

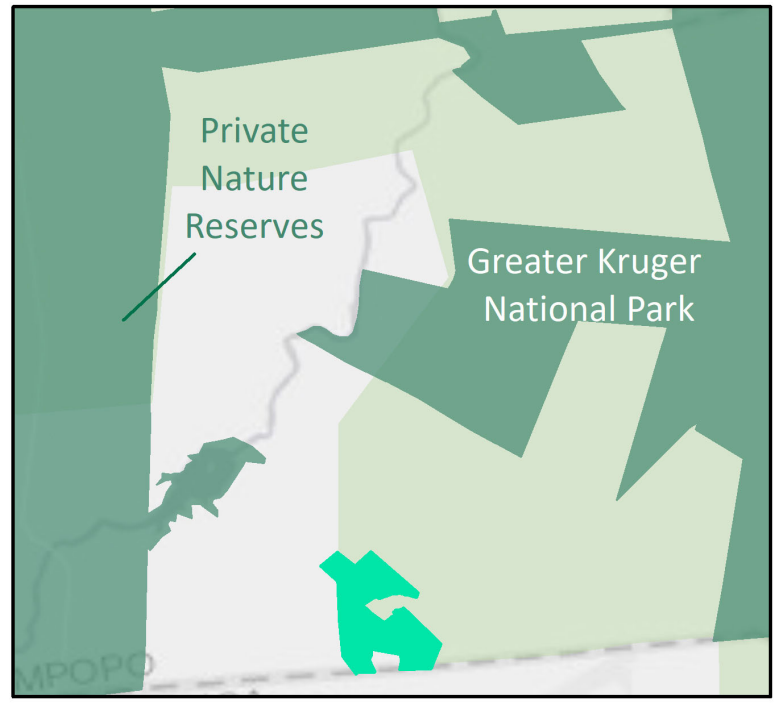

Candidate OECM 2: Academic Institute

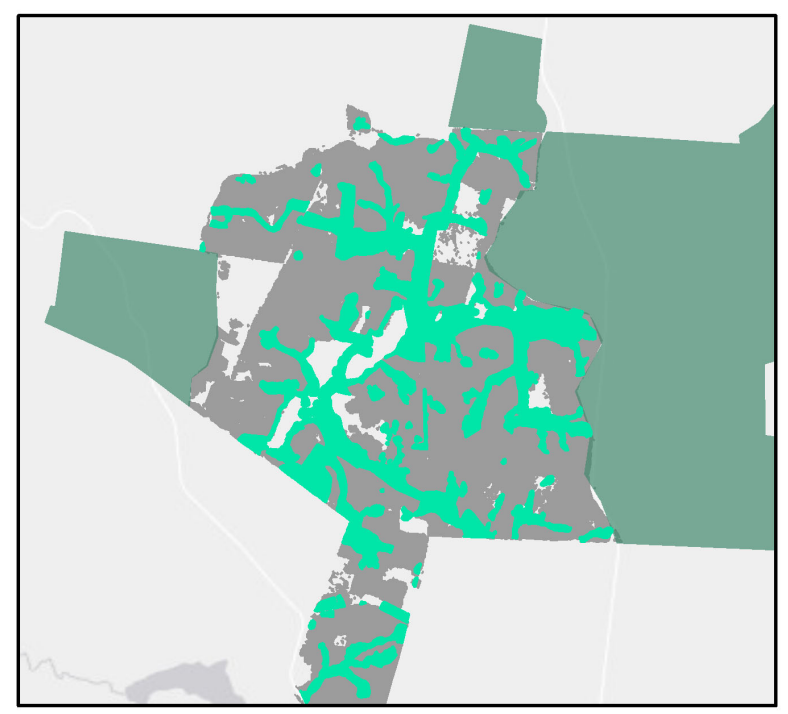

Candidate OECM 4: Government -

State Forestry Site

\section{Legend}

Candidate OECM

Protected Areas

(SAPAD)

Other Conservation

Areas

Figure 3. Candidate OECM sites 
area-based conservation outcomes and recognise and support these sites as OECMs. This site clearly illustrates that when management objectives are intentionally aligned with sustainable land use, and governance mechanisms are strengthened, conservation outcomes are achieved.

\section{Candidate OECM 2: Academic Institute}

The academic research facility (Figure 3) is privately owned and governed by a university and is used for educational research purposes. The site is a Knowledge Hub for Rural Development, focusing on ecological and social research and training in the area. The university has demonstrated long-term intent through substantial investment in research and other infrastructure at the site. Research results also provide a better understanding and management of the associated savannah ecosystems. It conducts engagement and research involving rural communities and where possible staff are employed from local villages. Conservation is a secondary management objective as the site is managed in favour of the intact natural habitat. Ancestral gravesites on the site are also protected.

\section{Candidate OECM 3: Government - Air Force Base}

The air force base is situated between two existing protected areas which form part of the Greater Kruger open system (Figure 3). The 2,400 hectare natural buffer zone area around the military infrastructure, which is used for training military personnel, was assessed as a candidate OECM. This intact habitat acts as a buffer and corridor between the neighbouring protected areas. The governance authority is the South African National Defence Force. All state-owned land and infrastructure are ultimately under the Department of Public Works' custodianship, but the specific government departments (in this case the Defence Force) are given all operational rights. The property's governance is underpinned by South Africa's Defence Act, No 42 of 2002.

This buffer zone is managed as a conservation area, supporting various threatened savannah species. Conservation is a secondary management objective. All aspects of environmental management, such as habitat condition assessments, burning regimes and game counts, are stipulated in the environmental management plan. Given the site is governed and managed by the Defence Force, the site's status is intended to be in place for the long term, and most internal and external risks and threats can be managed. The only potential future threat is a reduction of state

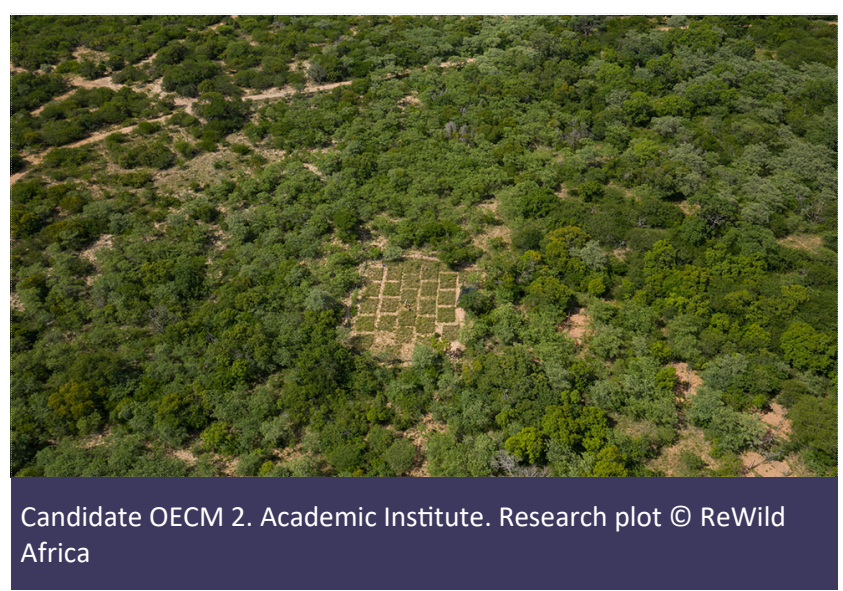

funds for the site's management, but this is highly unlikely.

\section{Candidate OECM 4: Government - State Forestry Site}

The Department of Public Works owns this state-owned commercial forestry site. The site is governed in line with the Management of State Forest Act 128 of 1992, which gives the Department of Forestry, Fisheries and the Environment (DFFE) and SAFCOL (parastatal entity) the right to manage state forest land.

The National Forest Act 84 of 1998, Chapter 1, Section 1, states that the purposes of this Act are to "promote the sustainable use of forests for environmental, economic, educational, recreational, cultural, health and spiritual purposes". Chapter 2, Section 3, states the principles, "forests must be developed and managed so as to (i) conserve biological diversity, ecosystems and habitats; conserve natural resources, especially soil and water".

Significant tracts of intact wetland and grasslands occur at the site and act as a corridor in a much larger wetland and grassland system, fulfilling critical ecosystem services. Only the intact wetland and grassland system was assessed and would be reported as the OECM. The

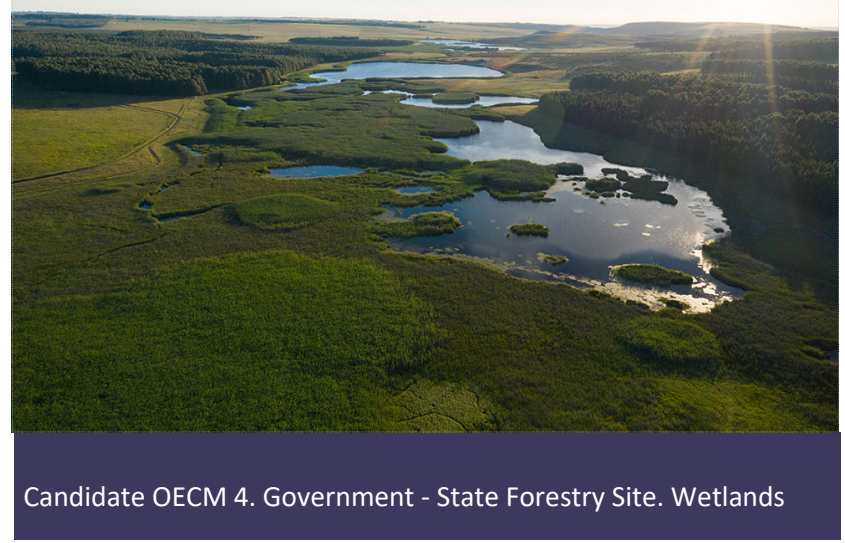


boundary of the wetlands and grasslands would therefore constitute the geographic boundary of the OECM (i.e. any commercial timber plantations would be excluded) (Figure 3). Specific conservation management objectives exist for these wetlands and grasslands and a dedicated environmental manager is employed to implement the environmental management plan for the natural habitat.

\section{OPPORTUNITIES AND CHALLENGES}

This study highlighted several opportunities offered through OECMs for promoting area-based conservation objectives in South Africa as well as the challenges to realise these. These core opportunities and challenges may be relevant to other countries. The key opportunities are summarised below.

The voluntary acceptance of the CBD's definition of OECMs by relevant government agencies and their support of stakeholders to assess and report sites as OECMs to the World Database on OECMs is imperative. Given their mandate, the DFFE can facilitate the institutionalisation of OECMs within South Africa's policy framework to ensure the alignment of OECMs with existing frameworks to recognise and report on conservation areas at a national level, as well as in meeting the international reporting requirements of the CBD.

For the OECM framework to strengthen a country's system of protected and conserved areas, the CBD Decision 14/8 (CBD, 2018) and any accompanying guidelines and assessment methodologies need to be aligned and integrated with the existing community of practice concerning the legal and practical recognition of unprotected conservation areas. In South Africa, this is underpinned by The Protected Areas Act and the biodiversity stewardship community of practice. OECMs could form part of the Biodiversity Stewardship Technical Working Group's mandate to undertake the integration, alignment, recognition, identification, reporting and strengthening of OECMs in South Africa.

Given international and national targets and proposed future targets for area-based conservation, South Africa

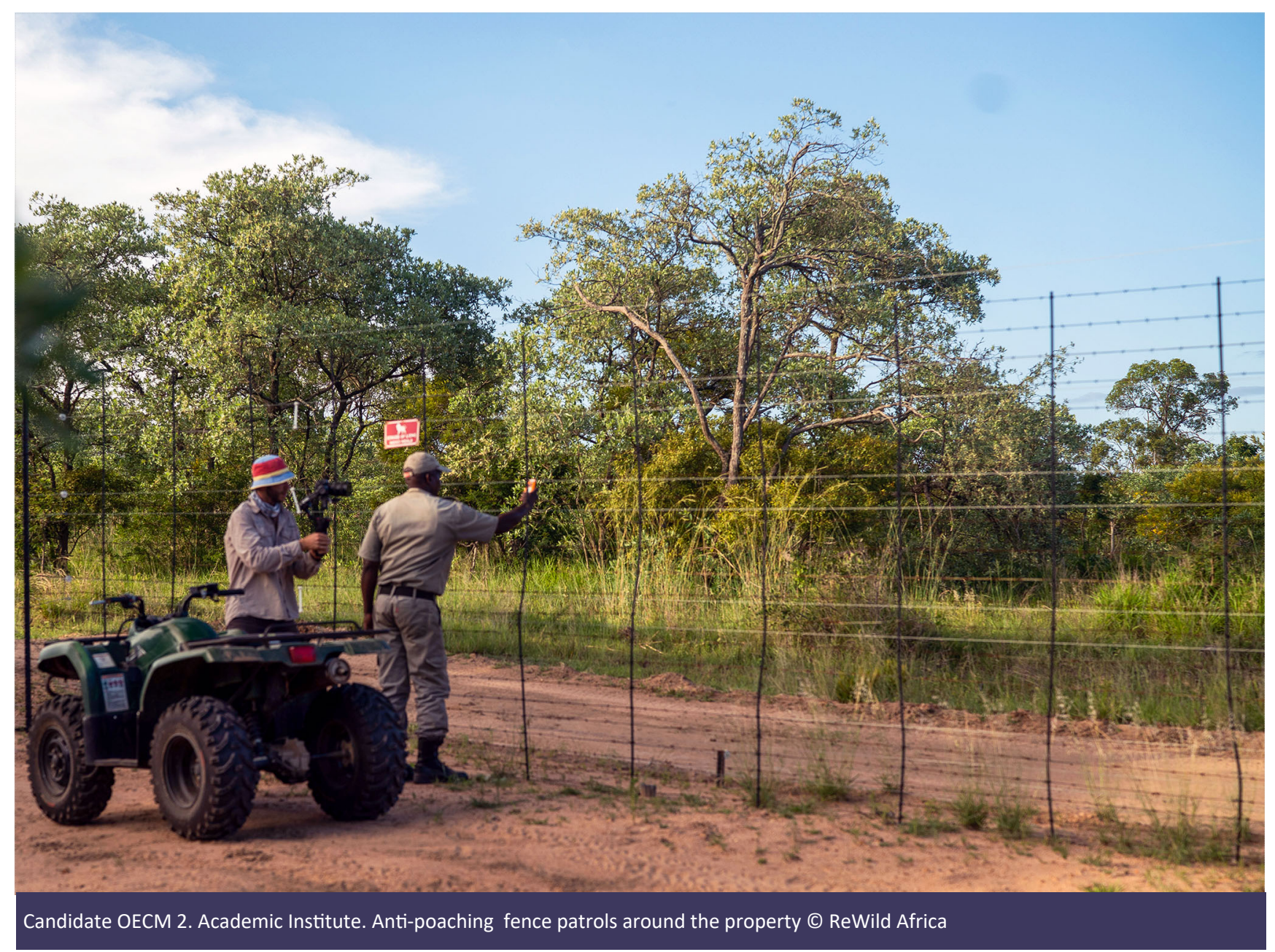


may expand its network of protected areas and conservation areas. OECMs allow for existing initiatives, outside of protected areas, to be recognised, and to strengthen their governance and management mechanisms leading to biodiversity conservation. OECMs could facilitate a more inclusive area-based conservation network by allowing the inclusion of previously excluded or marginalised groups of land use types.

The CBD Aichi Target 11 (2010) refers to conserving "especially areas of particular importance for biodiversity and ecosystem services", and the CBD definition (CDB, 2018) refers to OECMs delivering "in situ conservation of biodiversity, with associated ecosystem functions and services...". For OECMs to deliver on these, they must first and foremost be identified based on their biodiversity attributes and ecosystem services value (Visconti et al., 2019). Given South Africa's extensive biodiversity spatial mapping and planning products, including the current national review and expansion of KBAs, these spatial products can be used to prioritise where OECM assessments should be focused. Noting that the extent of biodiversity mapping and prioritisation varies across national contexts, the best available biodiversity data should be used for OECM assessments.

Ecological infrastructure refers to naturally functioning ecosystems that deliver valuable services to people. Critical ecological infrastructure includes Strategic Water Source Areas vital to the national economy (WWF-SA, 2013). It is recommended that Strategic Water Source Areas be prioritised for identifying and assessing potential OECMs to foster a landscape approach to securing Strategic Water Source Areas, alongside protected areas and sustainable agriculture.

The CBD Decision 14/8 (CBD, 2018) and the IUCN guidelines (IUCN-WCPA, 2019) underscore that OECMs should be supported with measures to enhance the governance capacity of their legitimate authorities and thereby secure their positive and sustained outcomes for biodiversity. The OECM assessment process may be used to motivate governance and management improvements. It is noted that local communities have integrated governance mechanisms that have both opportunities and challenges which may be enhanced or addressed through OECM assessments. The OECM framework provides a suitable benchmark against which to evaluate and assess the level of support needed to strengthen these structures accordingly.
Many of the activities underpinning South Africa's Wildlife Economy, described under the Biodiversity Economy Strategy (DEA, 2016), are already promoting or potentially aligned with area-based conservation. Local communities are often the primary beneficiaries of the Wildlife Economy and the associated green jobs. Well-governed and sustained governance and management structures in these communities will vitally underpin their successful engagement in the Wildlife Economy. OECMs offer a framework by which to assess and guide the strengthening of the governance and management of these community-owned sites, and thereby support the Biodiversity Economy Strategy and the Land Reform and Biodiversity Stewardship Initiative $^{4}$. Further investigation is needed to understand how OECMs may provide a global framework that can underpin legitimate, diverse and sustainable economic opportunities and conservation financing that merges with rural economies and in-situ biodiversity conservation outcomes. Using a global framework could address issues of risk for investors in various projects embedded in the Biodiversity Economy.

Results from this project indicate that South Africa has many potential OECMs and that each should be assessed at a site level. Key challenges will be mobilising additional capacity and resources for assessing, supporting and monitoring sites. Resources are already limited under biodiversity stewardship and there is a justifiable concern that resources may be diverted away from protected areas to OECMs. Therefore, partnerships between the public, private and civil society sectors are essential to assess OECMs collectively across the broader landscape. A strong ethos of collaboration already exists at national and provincial levels through biodiversity stewardship. Utilising the Biodiversity Stewardship Technical Working Group (TWG) and provincial level biodiversity stewardship working groups can mobilise capacity and resources for OECM assessments. Also, OECM assessments focused on areas or landscapes with a high probability of meeting the criteria are essential for maximising resources (Supplementary Online Material Table S2). The list of potential OECMs generated through this study should be a starting point to identify sites for assessment, particularly where there is direct alignment with biodiversity stewardship category 2 . These mechanisms are also being implemented and designated by a broad community of practice that is well organised through the Biodiversity Stewardship TWG. Therefore, efforts to assess OECMs should be aligned with biodiversity stewardship, to ensure collaboration and to pool resources. 


\section{CONCLUSION}

OECMs provide a global framework to recognise, complement and strengthen other conservation area designations and existing management and governance mechanisms, contributing to CBD Aichi Target 11 (and its post-2020 inheritor target). South Africa's national OECM review highlighted opportunities for South Africa and has generated lessons for other countries. Through proper technical and policy alignment, the OECM framework will facilitate the reporting of South Africa's conservation estate nationally and internationally, assisting with formalising conservation areas in South Africa. This alignment will also address potential challenges by facilitating resource use efficiency and mobilization, and mitigate the reporting of non-compliant sites. In addition, OECMs provide an opportunity to create more interconnected landscapes and seascapes in combination with protected areas. Significantly, they facilitate the inclusion of a diverse range of rights-holders and stakeholders contributing to area-based conservation. These include previously marginalised groups, land use types, and sectors. OECMs can play a role in supporting local economies that are simultaneously safeguarding biodiversity and ecological assets. They offer an opportunity to strengthen governance structures that can attract conservation finance investment. Looking ahead, OECMs offer South Africa a unique tool that addresses environmental, social and economic priorities. Sharing the lessons from South Africa's experience may also help other countries assess OECMs and the potential benefits OECMs offer landscapes across the African continent and globally.

\section{ENDNOTES}

1 Key Biodiversity Areas (KBAs) are the most important places in the world for species and their habitats (IUCN, 2016).

2 Protected areas on private or communal land.

3 This initial draft tool followed a similar assessment methodology to the tool developed by the Canadian Council on Ecological Areas which was shared with this project: a draft guidebook "... for the identification and for the application of IUCN Protected Area Categories" (CCEA, 2018).

4 The Land Reform and Biodiversity Stewardship Initiative (LRBSI) is a conservation and developmental initiative run in a tri -partnership by the Department of Rural Development and Land Reform (DRDLR), the Department of Forestry, Fisheries and Environment (DFFE) and the South African National Biodiversity Institute (SANBI).

\section{SUPPLEMENTARY ONLINE MATERIAL}

Online resources - Tables $\mathrm{S} 1$ and $\mathrm{S} 2$

\section{ACKNOWLEDGEMENTS}

This project was commissioned by the IUCN World Commission on Protected Areas Task Force on Other
Effective Area-Based Conservation Measures and funded by the Leonardo Di Caprio Foundation. The project was a collaborative effort between BirdLife South Africa, Wilderness Foundation Africa, Kruger to Canyons Biosphere Region NPC, South African National Biodiversity Institute (SANBI), Department of Forestry, Fisheries and the Environment (DFFE), Future Law and the IUCN-WCPA OECM Specialist Group.

\section{ABOUT THE AUTHORS}

Daniel Marnewick is the Regional Programme Officer for the IUCN Green List of Protected and Conserved Areas (IUCN-Eastern and Southern Africa Regional Office), and Chair of the Key Biodiversity Areas Community. He specialises in biodiversity prioritisation, e.g. Key Biodiversity Areas, and area-based conservation mechanisms, primarily privately protected areas, other effective area-based conservation measures, and the IUCN Green List. He is a member of the IUCN-WCPA and the OECM Specialist Group

Candice M. D. Stevens is Head of Innovative Finance \& Policy at Wilderness Foundation Africa and Chair of the Sustainable Landscape Finance Coalition. Candice is a member of the IUCN-WCPA, IUCN PPA Specialist Group and the OECM Specialist Group. She is the recipient of the UN Pathfinder Award Special Commendation for protected and conserved area innovation.

Harry Jonas, based in Sabah (Malaysia), is an international environmental and human rights lawyer, co-founded Natural Justice and Future Law and supports the ICCA Consortium and Forever Sabah. Harry co-chairs the IUCN WCPA's OECM Specialist Group. He is a Fellow at Ashoka, CISDL and UNEPWCMC.

Romy Antrobus-Wuth is the Stewardship Ecologist for the UNESCO designated Kruger to Canyons Biosphere Region. She supports work on expanding protected areas, formalising OECMs and improving land management practices for improved biodiversity and water conservation in the region. She also sits on the national OECM Steering Committee.

Natasha Wilson is the Chair of the Biodiversity Stewardship Technical Working Group, and Biodiversity Stewardship Advisor for the South African National Biodiversity Institute. She focuses on protected area expansion through biodiversity stewardship. Her professional expertise and competencies include policy and strategy development, co-operative governance, capacity building, conservation stewardship 
implementation, land trust strategy development and implementation.

Nicholas Theron has over 10 years' experience implementing measures to conserve and expand protected areas in South Africa. He is the Senior Programme Manager with the Kruger to Canyons Biosphere Region providing strategic direction and guiding the organisation's protected area expansion work in the region. Nicholas sits on the Biodiversity Stewardship Technical Working Group.

\section{REFERENCES}

CBD (2018). Protected areas and other effective area-based conservation measures (Decision 14/8). https://www.cbd.int/ doc/decisions/cop-14/cop-14-dec-08-en.pdf

CCEA (2018). Protected Areas and Other Effective Area-Based Conservation Measures in Canada: A Guidebook for Their Identification and For the Application of IUCN Protected Area Categories. Consultation Draft Version 1 - May 2018. Canadian Council on Ecological Areas.

DEA (2016). National Biodiversity Economy Strategy (NBES). Published March 2016, Department of Environmental Affairs, Pretoria.

DEA (2015). National Biodiversity Strategy and Action Plan. Department of Environmental Affairs, Pretoria.

DEA (2003). National Environmental Management: Protected Areas Act, No. 57 of 2003 (NEMPAA). Department of Environmental Affairs, Pretoria.

Donald, P.F., Buchanan, G.M., Balmford, A., Bingham, H., Couturier, A.R., de la Rosa Jr., G.E., Gacheru, P., Herzog, et al. (2019). The prevalence, characteristics and effectiveness of Aichi Target 11's "other effective area-based conservation measures" (OECMs) in Key Biodiversity Areas. Conservation Letters, 2019;e12659. DOI: 10.1111/conl.12659. https:// doi.org/10.1111/conl.12659.

Dudley, N., Holly, J., Nelson, F., Parrish, J., Pyhälä, A., Stolton, S. and Watson, J.E.M. (2018). The essential role of other effective area-based conservation measures in achieving big bold conservation targets. Global Ecology and Conservation 15, e00424.

Hill, R., Adem, Ç., Alangui, W.V., Molnár, Z., AumeeruddyThomas, Y., Bridgewater, P., Tengö, M., Thaman, R., Yao, C.Y.A., Berkes, F. and Carino, J. (2020). Working with indigenous, local and scientific knowledge in assessments of nature and nature's linkages with people. Current Opinion in Environmental Sustainability 43:8-20.

IUCN (2016). Global Standard for the Identification of Key Biodiversity Areas, Version 1.0. First edition. Gland, Switzerland: IUCN.
IUCN-WCPA (2019). Recognising and reporting other effective area-based conservation measures. Gland, Switzerland: IUCN.

IUCN-WCPA (Forthcoming). Site-level methodology for identifying other effective area-based conservation measures (OECMs). Gland, Switzerland: IUCN. Online: https://www.iucn.org/ commissions/world-commission-protected-areas/our-work/ oecms/oecm-reports

Jonas, H.D., Lee, E., Jonas, H.C., Matallana-Tobon, C., Wright, K.S., Nelson, F. and Enns, E. (2017). Will "other effective area -based conservation measures" increase recognition and support for ICCAs? PARKS 23(2):63-78.

Marnewick, D., Stevens, C.M.D., Antrobus-Wuth, R., Theron, N., Wilson, N., Naude, K. and Jonas, H. (2020). Assessing the Extent of OECMs in South Africa: Final Project Report. Johannesburg: BirdLife South Africa. Online: https:// www.birdlife.org.za/wp-content/uploads/2020/11/OECMReport-2020-Low_Res-1.pdf

Mitchell, B.A., Fitzsimons, J.A., Stevens, C.M.D. and Wright, D.R. (2018). PPA or OECM? Differentiating between privately protected areas and other effective area based conservation measures on private land. PARKS 24 Special Issue: $49-60$. DOI: 10.2305/IUCN.CH.2018.PARKS-24-SIBAM.en

SANBI (2018). Biodiversity Stewardship Guideline. A guideline produced for the Department of Environment, Forestry and Fisheries. Developed by Wilson, N., Kershaw, P., Marnewick, D. and Purnell, A.

SANBI (2017). The business case for biodiversity stewardship. A report produced for the Department of Environmental Affairs. Developed by Cumming, T., Driver, A., Pillay, P., Martindale, G., Purnell, K., McCann, K. and Maree, K. Pretoria: South African National Biodiversity Institute.

SANBI (2016). Lexicon of Biodiversity Planning in South Africa. Beta Version, June 2016. Pretoria: South African National Biodiversity Institute. $72 \mathrm{pp}$.

Stevens, C.M.D. (2019). International Outlook for Privately Protected Areas: South Africa Country Profile. International Land Conservation Network (a project of the Lincoln Institute of Land Policy) - United Nations Development Programme.

Visconti, P., Butchart, S.H.M., Brooks, T.M., Langhammer, P.F., Marnewick, D., Vergara, S., Yanosky, A. and Watson, J.E.M. (2019). Protected area targets post-2020. Science 364 (6437):239 -241.

Wright, D.R, Stevens, C.M.D, Marnewick, D, and Mortimer, G. (2018). Privately Protected Areas and Biodiversity Stewardship in South Africa: Challenges and Opportunities for Implementation Agencies. PARKS 24.2 November 2018: 4562. 10.2305/IUCN.CH.2018.PARKS-24-2en

WWF-SA (2013). Defining South Africa's Water Source Areas. Prepared by: Nel, J., Colvin, C., Le Maitre, D., Smith, J., and Haines, I. Published by WWF-World Wide Fund For Nature, Cape Town, South Africa. 


\section{RESUMEN}

En 2018, las Partes del Convenio sobre la Diversidad Biológica (CDB) adoptaron una definición y criterios para identificar otras medidas efectivas de conservación basadas en áreas (OMEC). Sudáfrica fue uno de los primeros países en emprender un examen general a nivel nacional de sus posibles OMEC. Los resultados de investigaciones anteriores ya estimaban que el 48,5\% de los sitios de Áreas clave para la biodiversidad no protegidas de Sudáfrica podrían ajustarse a la definición de OMEC. Un estudio posterior de diversos grupos interesados brindó la oportunidad de evaluar la concordancia entre las OMEC y las políticas y prácticas nacionales de conservación, para determinar de modo más preciso el alcance potencial de las OMEC, y si estas pueden reforzar el patrimonio colectivo de conservación del país. Este estudio arrojó varias conclusiones. En primer lugar, el marco de las OMEC facilita la formalización, expansión e información relacionada con el patrimonio de las áreas de conservación de Sudáfrica. En segundo lugar, las OMEC refuerzan los paisajes terrestres y marinos interconectados junto a las áreas protegidas. En tercer lugar, las OMEC pueden incluir una amplia gama de titulares de derechos que contribuyen a la conservación basada en áreas, incluidos grupos, tipos de uso de la tierra y sectores anteriormente marginados. En cuarto lugar, las OMEC desempeñan una función de apoyo a las economías locales que simultáneamente salvaguardan el patrimonio medioambiental. Sigue planteando dificultades el aprovechamiento de los recursos humanos y financieros para evaluar, informar, custodiar y apoyar a las OMEC, sin desviar recursos de otras prioridades de conservación, especialmente en lo concerniente a las áreas protegidas.

\section{RÉSUMÉ}

En 2018, les Parties à la Convention sur la diversité biologique (CDB) ont adopté une définition et des critères pour identifier les autres mesures de conservation efficaces par zone (AMCE). L'Afrique du Sud est l'un des premiers pays à entreprendre un examen national complet de ses AMCE potentielles. Les résultats de recherches antérieures avaient estimé que 48,5 pour cent des sites situés dans les zones clés de la biodiversité non protégées d'Afrique du Sud pourraient potentiellement répondre à la définition de l'AMCE. Une étude multipartite ultérieure a permis d'évaluer l'alignement entre les AMCE et les politiques et pratiques nationales de conservation, d'étudier davantage l'étendue potentielle des AMCE et de déterminer si les AMCE pourront renforcer le domaine de conservation au niveau national. Cette étude a abouti à plusieurs conclusions. Premièrement, que le cadre des AMCE facilite la formalisation, l'extension et le reporting des aires de conservation en Afrique du Sud. Deuxièmement, que les AMCE renforcent les environnements terrestres et maritimes interconnectés se trouvant près des aires protégées. Troisièmement, que les AMCE peuvent contenir un large éventail d'éléments qui impactent la conservation par zone, tels les groupes marginalisés, des modes d'utilisation des terres et des secteurs. Quatrièmement, que les AMCE jouent un rôle dans le soutien des économies locales qui protègent les actifs environnementaux. Un défi de taille demeure : celui de mobiliser les ressources financières et humaines pour évaluer, rendre compte, suivre et soutenir les AMCE, sans détourner les ressources d'autres priorités de conservation, en particulier des aires protégées. 